\title{
29. Studium über die Beziehungen zwischen anorganischen Salzen, vegetativen Giften und Hormonen.
}

III. Mitteilung.

\section{Der Einfluss der Pituitrininjektion auf die Verteilung der anorganischen Salze und Ionen im Blutserum.}

Teru Mozai, Minoru Agiya, Jun Inada, Shinichi Kawasgima.

(Aus d. med. Klinik von Prof. R. Inada, Kaiserl. Univers. Tokyo.)

(Rec. Feb. 1, 1927. Comm. by K. MiurA, M.I.A., Feb. 12, 1927.)

Bei diesen Versuchen wurden die Veränderungen der anorganischen Salze und Ionen des Serums infolge der Pituitrininjektion (subcutan $1 \mathrm{ccm}$ Park Davis) untersucht. Die Bedingungen waren dieselben wie bei den vorigen Versuchen. Die klinischen Erscheinungen nach der Injektion, wie Veränderung des Blutdruckes, Blässe der Haut, Harn- und Stuhldrang, Kolik- sowie Blasenschmerz wurden genau beobachtet. Die Ergebnisse aus 12 Versuchsfällen werden in den folgenden Zeilen kurz geschildert: Das Hämoglobin und das Serumeiweiss veränderten sich wenig. Die Chloride im Serum nahmen in 6 Fällen $a b$, in 2 zu und blieben in 4 Fällen unverändert. Demnach kann man hier mehr von einer Senkung des Chlorspiegels sprechen als von dessen Erhöhung, was gegen den Befund spricht, den einige Forscher bei Tierexperimenten gefunden zu haben glauben. Die Verschiebung der Wasserstoffionenkonzentration blieb fast in allen Fällen aus, während beim Kohlensäuregehalt eine Neigung zur Verminderung zu konstatieren war. Gegen unsere Erwartung, die sich auf den Befund der Harnanalyse d. i. die regelmässige Vermehrung des Kaliums in demselben stützte, wurde eine grobe Schwankung des Serumkaliumwertes hier nicht konstatiert. Dennoch war hier in der Mehrzahl der Fälle eine geringe, immerhin aber noch nachweisbare Verminderung zu erkennen. Der Calcium- sowie der anorganische Phosphorspiegel des Serums war meist unverändert, während das Serummagnesium in 2 von 4 Füllen zunahm. Betreffs des Gehalts des 
nur unbedeutende Zunahme nachgewiesen, während in keinem Falle eine deutliche Verminderung festgestellt wurde.

Beziehungen der einzelnen Serumbestandteile zu einander.

Der Kohlensäuregehalt venösen Plasmas war hier etwas abgenommen, ohne jedoch dessen $\mathrm{Ph}$ zu ändern. Dadurch allein ist es schwer zu entscheiden, nach welcher Richtung nun eigentlich der Plasmapuffer sich verschob. Hier mag aber die obenerwähnte Vermehrung des Serumnatriums von gewisser Bedeutung sein und eine acidotische Veränderung vermuten lassen. Denn, während die Veränderung der gesamten Anionen gering und inkonstant war, vermehrte sich die Summe der gesamten Kationen des Serums. So wird demnach der "Kationenüberschuss", welcher nach Gollwitzer-Meyer und anderen Autoren im normalen Serum vorhanden sein soll, fast bei jeder Analyse vergrössert gefunden. Dieser erhöhte Kationenüberschuss könnte wohl nach den Autoren auf der Vermehrung unbekannter Sïureradikale im Serum beruhen. Auch mag jene unbedeutende Kaliumverminderung auf dessen Verdrängung durch vermshtes Natrium zurückgeführt werden. Doch ist diese Erhöhung des Serumnatriumgehalts zu klein, um ohne weiteres auf diese Verdrängungserscheinung schliessen zu lassen. Was das Säurebasengleichgewicht anbetrifft, waren seine Veränderungen sehr klein, obwohl die Reaktion nach derselben Richtung hin wie bei Adrenalin stattgefunden zu haben scheint. Im grossen und ganzen waren die Befunde bei der Serumanalyse sehr verschieden and solche Regelmässigkeit der Befunde wie bei der Harnanalyse, welche in der Vermehrung der Kalium- und der Verminderung der Natriumausscheidung ihren Ausdruck fanden, waren hier nicht mehr mit Deutlichkeit zu erkennen. 